\title{
Home on the Gun Range: Discussing Whether Kansas's New Stand Your Ground Statute Will Protect Gun Owners Who Use Disproportionate Force in Self-Defense
}

\section{INTRODUCTION}

On October 8, 2006, Norman Borden was walking his four pit bulls in West Palm Beach, Florida, when he got into an altercation with two young men. ${ }^{1}$ The men exchanged heated words, and Borden showed the men that he had a gun. The two young men left and went to pick up a third man, who was a "documented member of a violent gang." 2 The three men returned in a Jeep, carrying bats, and started to drive toward Borden. $^{3}$ In response, he shot at the vehicle fourteen times. ${ }^{4}$ After shooting five times through the windshield, Borden walked around to the driver's side and shot into the car nine more times. ${ }^{5}$ Two of the three men in the car were killed, and the other man was critically wounded. ${ }^{6}$ During Borden's murder trial, the prosecution argued that the first five shots were in self-defense, but the last nine shots were murder. However, under Florida's new "stand your ground" law, all of Borden's actions were considered self-defense, and he was acquitted. ${ }^{9}$ Florida's law allows the use of deadly force in self-defense when reasonably

\footnotetext{
Annie Wells. J.D. candidate 2009, University of Kansas School of Law. B.A. 2005, Trinity University. I would like to thank Professor Jelani Jefferson for her assistance with this Note. I would also like to thank David Shank for his insight, and my family for their constant support.

1. Nancy L. Othón, Free but in Fear of Reprisal_Man Acquitted of Murder, but Living Under Threat, S. FLA. SUN-SENTINEL, July 1, 2007, at 1A.

2. Id.

3. Id.

4. Id.

5. Id.

6. Id.

7. Larry Keller, Jury Acquits Shooter in Castle Doctrine Case-Borden Said He Killed Two Attackers in Self-Defense, PALM BEACH PoST, June 26, 2007, at 1A.

8. Fla. StAT. ANN. $\$ 776.013$ (West 2005) (effective Oct. 1, 2005)

9. Othón, supra note 1.
} 
necessary and does not require that a person retreat before using deadly force. $^{10}$

In May, 2006, Kansas passed a new "stand your ground" law. ${ }^{11}$ Kansas's stand your ground law is similar to Florida's in several ways, but it does not include a reasonableness requirement, and it does not expressly provide for-or limit — the use of deadly force. If the events of the Borden case had occurred in Kansas, it is possible that Borden may not even have been tried for his actions. Because there is no reasonableness requirement in Kansas's new statute, there would not have been any inquiry into the reasonableness of the last nine shots. Rather, Borden may have been protected by the new stand your ground law, which allows a person to "meet force with force" when "attacked" in any place where he "has a right to be." 12 In addition to this new statute, Kansas also has separate defense of person ${ }^{13}$ and defense of dwelling ${ }^{14}$ statutes, each of which was amended in 2006 to include the right to use deadly force and to abrogate any duty to retreat. Kansas's new stand your ground law is unclear and ambiguous. The law does not define critical terms and provides no standard for courts to follow when applying the statute. The law includes no requirement of reasonableness or proportionality, and does not indicate the amount of force allowed. The other defense statutes may be applied when deadly force is used, but nothing in the stand your ground law precludes courts from applying that law when deadly force is used, even disproportionately. Unfortunately, it is unclear what the exact outcome would have been for Borden in Kansas because Kansas's new stand your ground law, though enacted almost two years ago, has not been interpreted by any Kansas court.

The stand your ground law was passed during the same legislative session as Kansas's new concealed carry statutes (collectively "concealed carry"). ${ }^{15}$ Concealed carry is likely to exacerbate the problems associated with the stand your ground law. Because people are now lawfully allowed to have guns concealed on their persons, it is possible that the stand your ground law will produce unwanted results involving gun-related violence. If a fight does result in gun violence, and neither party has a duty to retreat, the stand your ground law may protect

10. Fla. Stat. ANN. § 776.013 (West 2005).

11. KAN. StAT. ANN. § 21-3218 (2006).

12. Id.

13. Id. \$21-3211.

14. Id. $\$ 21-3212$.

15. Id. $\S \$ 75-7 \mathrm{c} 01$ through $7 \mathrm{c} 12$. 
the party who kills his challenger-even if the killer acted unreasonably, and even if he could have retreated safely.

This Note will address problems likely to arise as a result of Kansas's stand your ground law and the new right to carry concealed firearms, and how those problems may be remedied or avoided through legislative or judicial action. First, I will provide background on the history of self-defense and retreat in the United States and Kansas, as well as background on the passage of the stand your ground law and concealed carry in Kansas. I will also discuss the problems with the stand your ground statute in greater detail and compare Kansas's stand your ground law to those in other states. This comparison will illustrate various ways the Kansas Legislature could improve the statutory language. Finally, I will argue that the stand your ground law should be amended to include definitions for the terms "attack" and "meet force with force," and that some standard of proportionality or reasonableness should be included. If the legislature declines to amend the statute, Kansas courts should define the terms of the statute narrowly, possibly inferring a reasonableness or proportionality standard within the statute.

Although it is important to protect a person who must act with force to defend himself or others, it is imperative that any protection granted by the legislature or the courts be unmistakably clear. Kansas's new stand your ground law does not meet this essential requirement, and this lack of clarity is likely to create serious problems without legislative or judicial intervention.

\section{BACKGROUND}

\section{A. Self-Defense Generally}

There are four common elements, or limitations, to the use of force in self-defense. ${ }^{16}$ These common elements provide that " 1 ) '[f]orce may be used only against an unlawful aggressor;' 2) '[t]he use of force must be strictly necessary;' 3) '[t]he amount of force must be proportional to the force being threatened;' and 4) '[t]he attack must be imminent.",17 Another important element of self-defense is that the action taken must

\footnotetext{
16. Michelle Jaffe, Comment, Up in Arms Over Florida's New "Stand Your Ground" Law, 30 Nova L. REV. 155, 158 (2005).

17. Id. at 158 (brackets in original) (quoting Whitley Kaufman, Is There a "Right" to SelfDefense?, 23 CRIM. Just. Ethics 20, 20-21 (2004)). See also Renee Lettow Lerner, The Worldwide Popular Revolt Against Proportionality in Self-Defense, 2 J.L. ECON. \& POL'Y 331, 332 (2006) ("[T]he prevention of harm cannot be achieved by causing harm that is disproportionate.").
} 
be reasonable. ${ }^{18}$ Reasonableness is hard to define, ${ }^{19}$ and different jurisdictions apply different standards. In New York's famous case, People v. Goetz, ${ }^{20}$ the New York Court of Appeals applied both objective and subjective tests in determining reasonableness. ${ }^{21}$ The court held that the jury must make two determinations: first, "whether the defendant ... believed deadly force was necessary" and second, "whether these beliefs were reasonable" in an objective sense. ${ }^{22}$ In other jurisdictions, courts have used a purely subjective standard. For example, in People $v$. $O^{\prime} \mathrm{Neal}^{23}$ the Supreme Court of Illinois held that "a defendant's reasonable belief as to the use of force, determined subjectively, justified the use of such force." ${ }^{24}$ Although different courts have applied different versions of reasonableness, the standard is nonetheless present in every jurisdiction's self-defense laws.

Kansas courts' interpretation of self-defense standards followed many of the same guidelines as those described above. In State $v$. Howard, ${ }^{25}$ the Kansas Supreme Court held that the defense of selfdefense requires that there "be a reasonable apprehension of imminent danger, and of the reasonableness of this apprehension the jury are to be the judges. A party assailed is justified in acting upon the facts as they appear to him, and is not judged by the facts as they are." 26 The court elaborated on this standard in State v. Davis, ${ }^{27}$ deciding that the test for reasonableness "is not what the circumstances actually were but whether the circumstances were such as appeared to the defendant at the time to be reasonably necessary to protect himself." 28 The Kansas Supreme Court's focus on the both the defendant's perspective and his reasonable apprehension of danger suggests the court regards the test for selfdefense as having both subjective and objective elements.

In 1969, the legislature passed three defense statutes-defense of persons, defense of dwellings, and defense of property ${ }^{29}$ - which were

8. Jaffe, supra note 16 , at 159 .

19. Id. at $159-60$.

20. 497 N.E.2d 41 (N.Y. 1986).

21. Id. at 52 .

22. Id.

23. 472 N.E.2d 441 (Ill. 1984).

24. John F. Wagner, Jr., Standard for Determination of Reasonableness of Criminal Defendant's Belief, for Purposes of Self-Defense Claim, that Physical Force Is Necessary-Modern Cases, 73 A.L.R. 4th 993, 1006 (1989) (citing People v. O'Neal, 472 N.E.2d 441 (1984)).

25. 14 Kan. 173 (1875).

26. Id. at $174-75$.

27. 218 P.2d 215 (Kan. 1950)

28. Id. at 217 (emphasis added) (citations omitted).

29. KAN. STAT. ANN. §§ 21-3211 through 3213 (1969). 
the original versions of the current defense statutes in Kansas. The defense of persons statute provided that "[a] person is justified in the use of force against an aggressor when and to the extent it appears to him and he reasonably believes that such conduct is necessary to defend himself or another against such aggressor's imminent use of unlawful force." ${ }^{30}$ In State v. Saleem, ${ }^{31}$ the Kansas Supreme Court quoted a jury instruction given in the trial court, which stated that the "justification [for selfdefense] requires both a belief on the part of the defendant and the existence of facts that would persuade a reasonable person to that belief." ${ }^{32}$ In enacting this statute, the Kansas Legislature codified the common law standard requiring both a subjective and an objective apprehension of imminent danger. The defense of dwelling statute used nearly identical language in reference to the protection of one's dwelling. ${ }^{33}$ Both the original defense of persons and defense of dwelling statutes contained reasonableness standards; however, neither specifically allowed for the use of deadly force, and neither mentioned an affirmative or negative duty to retreat. ${ }^{34}$ While these statutes were in effect, Kansas courts ruled that there was no duty to retreat before using force against an attacker, even when deadly force was used. In State v. Scobee, ${ }^{35}$ the Kansas Supreme Court held that, although the self-defense statute did not mention whether there was a duty to retreat, Kansas common law did not require that a person against whom force is threatened must retreat. ${ }^{36}$

\section{B. The Retreat Rule}

\section{English and Early American Views}

English common law required retreat in self-defense cases, if practicable, before the use of deadly force. ${ }^{37}$ This rule's purpose was to promote civility within society and "retain control of quarrels between individuals." ${ }^{38}$ However, this rule was discarded early in the United

\footnotetext{
30. Id. § 21-3211.

31. 977 P.2d 921 (Kan. 1999).

32. Id. at 930 .

33. $\$ 21-3212$.

34. $\$ \S 21-3211$ through 3212.

35. 748 P.2d 862 (Kan. 1988).

36. Id. at 867. See also infra Part II.B.2.

37. Jaffe, supra note 16 , at 160.

38. Id.
} 
States. ${ }^{39}$ One explanation for this change is that a "duty to retreat ... fit poorly into a political ideology that saw individuals as possessing natural rights, including the right to violent recourse ...."40 American courts instead promoted the idea that "a true man, who is without fault, is not obliged to fly from an assailant, who, by violence or surprise, maliciously seeks to take his life or do him enormous bodily harm." ${ }^{41}$ This rule is applied almost uniformly in each state, at least to the extent that no state requires retreat from one's home. ${ }^{42}$ The "rationale [for the exception to the English common law rule] is that there is not (or at least should not be) a place safer than home." 43 This exception is commonly referred to as the "castle doctrine." 44

Now many states-including Alabama, Texas, Florida, and Kansas-have adopted a no duty to retreat rule in some form by statute. ${ }^{45}$ Each of these statutes, with the exception of Kansas's, includes a reasonableness requirement. ${ }^{46}$ These reasonableness requirements appear in one of three forms: (1) a separate provision with its own reasonableness standard; (2) a no-duty-to-retreat provision included in the general self-defense statute; or (3) a separate provision that is subject to the reasonableness standard of a different section. Florida's selfdefense statute, which passed in 2005, includes a presumption of reasonableness. A person's use of deadly force in his home is presumed to be reasonable under specifically enumerated circumstances. ${ }^{47}$ Florida also enacted a stand your ground law, which allows the use of force, including deadly force, when reasonably used to defend against an attacker. $^{48}$ In 2007, Texas amended its self-defense law to include a presumption of reasonableness when force-including deadly force-is used in the defense of persons or dwellings. ${ }^{49}$ Texas's statute also

39. See Garrett Epps, Any Which Way but Loose: Interpretive Strategies and Attitudes Toward Violence in the Evolution of the Anglo-American "Retreat Rule," 55 LAW \& CONTEMP. PROBS. 303, 311 (1992) (citing a Georgia Supreme Court case from 1855 as one of the early manifestations of this change).

40. Id.

41. Erwin v. State, 29 Ohio St. 186, 199-200 (1876)

42. Jaffe, supra note 16, at 168.

43. Steven P. Aggergaard, Note, Criminal Law-Retreat from Reason: How Minnesota's New No-Retreat Rule Confuses the Law and Cries for Alteration-State v. Glowacki, 29 WM. MITCHELL L. REV. 657, 665 (2002).

44. Jaffe, supra note 16 , at 168 .

45. Ala. Code § 13A-3-23 (2007); Fla. Stat. AnN. § 776.013 (West 2008); Kan. Stat. AnN. $\S 21-3218$ (2007); TEX. PENAL CODE ANN. § 9.31 (Vernon 2007).

46. Ala. Code § 13A-3-23; Fla. Stat. Ann. § 776.013; Tex. Penal Code Ann. § 9.31.

47. FLA. STAT. ANN. § 776.013(1).

48. Id. $\S 776.013(3)$.

49. Tex. Penal Code AnN. $\S 9.31-9.32$. 
includes a list of offenses that create a presumption of reasonableness for any retaliating victim. ${ }^{50}$ Alabama's statute, amended in 2006 , is an example of a no duty to retreat provision that incorporates a reasonableness standard from the general self-defense statute. ${ }^{51}$

\section{The Retreat Rule in Kansas Case Law}

Kansas, like many other states, determined that a person should not be required to retreat before using force to protect his own life. ${ }^{52}$ The Kansas Supreme Court first decided this issue in State v. Reed by summarily asserting the principle in the court's Syllabus. ${ }^{53}$ In State $v$. Hatch $^{54}$ the Kansas Supreme Court affirmed its earlier assertion, stating that " $[\mathrm{t}] \mathrm{he}$ doctrine that a party unlawfully attacked must 'retreat to the wall,' before he can be justified in taking the life of his assailant in selfdefense, does not obtain in this state." ${ }^{55}$ More recently, in State $v$. Scobee ${ }^{56}$ the court reversed the murder conviction of a defendant who killed two aggressors in his driveway. The Kansas Supreme Court relied on several earlier cases, including Reed and Hatch, in determining that the omission of an instruction on retreat was reversible error because the prosecution relied on an erroneous argument that the defendant had a duty to retreat. ${ }^{57}$ Following Scobee, the Kansas Supreme Court decided State v. Ricks. ${ }^{58}$ In Ricks, the court determined that the defendant was not entitled to a no-duty-to-retreat jury instruction because he was not at home when the incident occurred. ${ }^{59}$ The court distinguished that case from Scobee, noting that defendant Scobee was in his driveway at the time of the shooting, while defendant Ricks was in a public parking lot. ${ }^{60}$ However, the court's decision in Ricks seems to rest on the fact that Ricks was the first aggressor in the altercation, not on the fact that he would have otherwise had an affirmative duty to retreat in a place outside the home. ${ }^{61}$

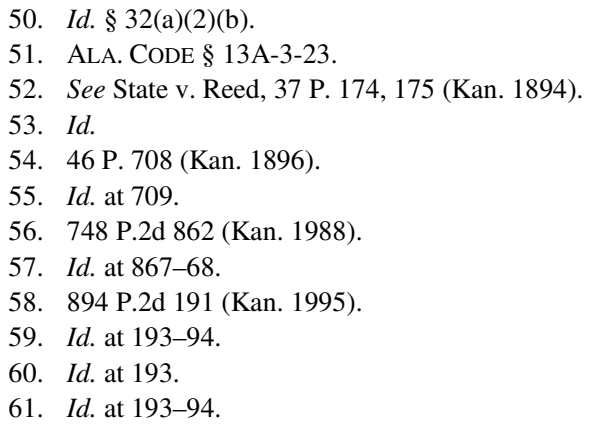




\section{Kansas's New Self-Defense and Retreat Rules}

In 2006, the Kansas Legislature amended the defense of persons and defense of dwelling statutes ${ }^{62}$ to include provisions regarding the use of deadly force and the duty to retreat. These amendments give a person the express right to use deadly force "if such person reasonably believes deadly force is necessary to prevent imminent death or great bodily harm." 63 The amendments also added a no-duty-to-retreat provision to Kansas's defense statutes. Both statutes now state that "[n]othing in this section shall require a person to retreat if such person is using force to protect such person or a third person." ${ }^{\text {"4 }}$ Therefore, when using deadly force in defense of one's self, a third person, a dwelling or an occupied vehicle, the person must act reasonably, and he does not have a duty to retreat before using deadly force.

In addition to these amendments, Kansas added the new stand your ground law. That law states that "[a] person who is not engaged in an unlawful activity and who is attacked in a place where such person has a right to be has no duty to retreat and has the right to stand such person's ground and meet force with force." ${ }^{, 65}$ This statute does not include any limitations on location or any requirement of reasonableness or proportionality. It also does not specify whether or not a person can use deadly force. Only one Kansas court has cited this statute, but the case did not discuss the scope or the possible application of the statute. ${ }^{66}$

\section{Concealed Carry in Kansas}

Roughly six weeks after the Kansas Legislature passed the stand your ground law, it passed Kansas's concealed carry statutes, allowing Kansans who qualify to obtain a permit to carry concealed firearms. ${ }^{67}$ The law passed over Governor Sebelius's veto. ${ }^{68}$ Most states' concealed carry statutes, including Kansas's, are "shall-issue" statutes, which

62. KAN. STAT. ANN. §§ 21-3211-12 (2006).

63. Id.

64. Id. $\S \S 21-3211(\mathrm{c}), 21-3212(\mathrm{c})$.

65. Id. $\S 21-3218$.

66. State v. Sola-Morales, 2008 WL 2510154 (June 20, 2008). In an unpublished table disposition, the Kansas Court of Appeals indicated that $\S 21-3218$ was intended to "expand the circumstances under which the "no-duty-to-retreat' rule is applicable in Kansas," but determined that the statute did not apply to the facts of the case. Id. at *12. The court also determined that the statute would apply only prospectively. Id.

67. KAN. STAT. ANN. §§ 75-7c01 through 7c12 (2006).

68. Governor's Message to the Senate, March 21, 2006. 
include several common characteristics. ${ }^{69}$ First, these statutes limit the discretion of the government body responsible for issuing permits. ${ }^{70}$ In other words, "[i]n a shall-issue statute, the local official must issue a permit to anyone who meets the basic requirements of the statute." ${ }^{, 71}$ Shall-issue statutes also generally include "language requiring a background check for purposes of detecting anything that might make the applicant a high risk for carrying a concealed weapon., ${ }^{, 72}$ Kansans who wish to obtain a concealed carry permit must satisfy an extensive list of qualifications, such as age, mental and physical capability, and the absence of a felony conviction. ${ }^{73}$ Many states, including Kansas, require that "applicants [] complete a gun safety course.," Shall-issue concealed carry statutes, including Kansas's, ${ }^{75}$ commonly designate "locations where a concealed weapon may not be carried regardless of whether or not a permit has been obtained."76 For example, concealed weapons are not allowed in courthouses, schools, or churches, among other places, even if the person carrying the weapons has a valid permit. ${ }^{77}$ Finally, most include a provision stating "whether the state will honor valid concealed-carry permits issued by other states."78 Kansas will honor another state's permit if the permit holder is not a Kansas resident and the attorney general determines that the standards for obtaining the other state's permit are acceptable. ${ }^{79}$

Concealed carry has been a hotly debated topic. One side of the debate argues that more guns in the hands of responsible individuals will bring down crime rates. ${ }^{80}$ This argument, made by John Lott and David Mustard, has been challenged and criticized. ${ }^{81}$ Jens Ludwig determined that the results obtained from Lott and Mustard's data were "due in part

69. Steven W. Kranz, Comment, A Survey of State Conceal and Carry Statutes: Can Small Changes Help Reduce the Controversy?, 29 HAMLINE L. REV. 638, 649 (2006).

70. Id.

71. Id.

72. Id. at 650 .

73. KAN. STAT. ANN. §§ 75-7c04(a)(2), (3), (4), (8) (2007).

74. Kranz, supra note 69, at 650; KAN. STAT. ANN. § 75-7c04(b).

75. $§ 75-7 \mathrm{c} 10$

76. Kranz, supra note 69 , at 651.

77. $§ 75-7 \mathrm{c} 10(\mathrm{a})(4),(13),(21)$.

78. Kranz, supra note 69 , at 652 .

79. $\$ 75-7 \mathrm{c} 03(\mathrm{c})$.

80. John R. Lott, Jr. \& David B. Mustard, Crime, Deterrence, and Right-to-Carry Concealed Handguns, 26 J. LEGAL STUD. 1, 1 (1997).

81. See generally Ian Ayres \& John J. Donohue III, Shooting Down the "More Guns, Less Crime” Hypothesis, 55 STAN. L. REV. 1193 (2003). 
or whole to unmeasured variables." ${ }^{, 82}$ Another article critical of Lott and Mustard's theory stated

that the statistical evidence that these laws have reduced crime is limited, sporadic, and extraordinarily fragile. Minor changes of specifications can generate wide shifts in the estimated effects of these laws. ... While we do not want to overstate the strength of the conclusions that can be drawn from the extremely variable results[,] . . . if anything, there is stronger evidence for the conclusion that these laws increase crime than there is for the conclusion that they decrease it. ${ }^{83}$

As these criticisms suggest, it is difficult to get completely accurate data about how often guns are used in defense. ${ }^{84}$ Estimates from some sources are too low because of unreported instances of defensive gun use. ${ }^{85}$ Some data, which comes from one-time telephone surveys, tends to "overstate the prevalence of defensive gun use because of 'telescoping,' ... self-presentation bias, and other sources of measurement error." ${ }^{\prime 86}$ The question that "remains controversial is whether enhanced regulation of gun ownership will increase or decrease crime. The reason behind this controversy is that, while guns make criminal violence more lethal, guns may also have the beneficial effect of enabling private citizens to defend themselves against criminal attack." ${ }^{, 87}$

Regardless of the laws enacted in any state, data shows that the majority of homicides, either justifiable or not, are committed using firearms. ${ }^{88}$ The Federal Bureau of Investigation's Criminal Justice Information Services Division compiles homicide data each year and creates tables showing the distribution of homicides based on various factors, including the states where the offenses occurred, weapons used, victim information, and circumstances of the offense. ${ }^{89}$ Several of those tables indicate that firearms are the most commonly used weapons in both murder and justifiable homicide cases. ${ }^{90}$ More specifically, 195 out

82. Jens Ludwig, Gun Self-Defense and Deterrence, 27 CRIME \& JUST. 363, 367 (2000).

83. Ayres \& Donohue, supra note 81, at 1201-02.

84. Ludwig, supra note 82, at 363.

85. See id. at 366 (discussing the results of the National Crime Victimization Survey).

86. Id.

87. Id. at 365

88. Department of Justice, Federal Bureau of Investigation, Criminal Justice Information Services Division, Crime in the United States, http://www.fbi.gov/ucr/cius2006/offenses/expanded_ information/homicide.html (last visited Apr. 12, 2008).

89. Id.

90. Department of Justice, Federal Bureau of Investigation, Criminal Justice Information Services Division, Expanded Homicide Data Table 6, http://www.fbi.gov/ucr/cius2006/offenses/ expanded_information/data/shrtable_06.html (last visited Apr. 13, 2008); Department of Justice, 


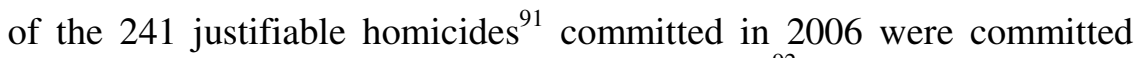
using a firearm-a handgun, rifle, or shotgun. ${ }^{92}$ Therefore, even if concealed carry laws do not directly change a state's crime rates, there may be an adverse effect based solely on the increased presence of weapons in that state.

\section{ANALYSIS}

\section{A. Problems with Kansas's Stand Your Ground Law}

There are two major problems with Kansas's stand your ground law. First, the statute's language is flawed. The text includes terms subject to multiple interpretations because they are not defined, and it includes no standard of reasonableness or proportionality. Second, the passage of the new stand your ground law may cause unforeseen problems in conjunction with the concealed carry law.

\section{Problems with the Statutory Language}

The language of the stand your ground law presents two problems for future interpretation and application. First, the terms of the statute are not defined, either in their meaning or in their scope. Second, there is no standard of reasonableness or proportionality in the statute.

In order for the statute to apply, a person must be "attacked." $" 93$ However, the term "attacked" is not defined. The dictionary definition of "attack" is fairly extensive; it includes both physical and verbal forms of "attack." The absence of a definition of "attack" is even more troublesome when viewed in conjunction with another clause of the statute. The statute also provides that when "attacked," a person can "meet force with force." 95 There is no indication of how much force would be appropriate for which type of attack. Because there is no indication of how much force is acceptable, it is possible that the statute will protect defensive uses of force that are disproportionate to the

Federal Bureau of Investigation, Criminal Justice Information Services Division, Expanded Homicide Data Table 14, http://www.fbi.gov/ucr/cius2006/offenses/expanded_information/data/ shrtable_14.html (last visited Apr. 13, 2008).

91. The FBI defines "justifiable homicide" in this context as "[ $\mathrm{t}] \mathrm{he}$ killing of a felon, during the commission of a felony, by a private citizen." Expanded Homicide Data Table 14, supra note 90.

92. Id.

93. KAN. STAT. ANN. § 21-3218(a) (2006).

94. OXFORD POCKET AMERICAN DiCTIONARY OF CURRENT ENGLISH 43 (2002).

95. § 21-3218(a). 
threatened force. For example, if someone is punched in the face, can he respond by attacking with a gun or knife? The answer is unclear under the current statutory language. Because there is no definition of "attack" or "meet force with force," or any indication of how those phrases should be interpreted, it is difficult to know what would be reasonable or proportionate in situations where the stand your ground law applies. It is possible that the actions of someone like Norman Borden, who fired an extra nine shots into a car full of people, would be presumed reasonable.

One central element of the defense of self-defense historically has been that the force used must be reasonable or proportionate to the aggressor's force. ${ }^{96}$ Unlike the other state statutes mentioned above, Kansas's stand your ground law does not even attempt to relate back to the reasonableness requirements of the other defense statutes. Without an express standard of reasonableness, or any reference to those standards included in the other defense statutes, it is unlikely that Kansas courts will interpret the statute as containing a reasonableness standard. The restrictions inherent in the rules of statutory construction, as discussed below, likely prevent such an interpretation. ${ }^{97}$

\section{Problems in Conjunction with Concealed Carry}

The problems with the stand your ground law will likely be exacerbated by the ability of Kansas citizens to carry concealed firearms. Concealed carry gives Kansans the ability to carry concealed firearms in many public places. ${ }^{98}$ As previously discussed, ${ }^{99}$ there is a list in the statute that limits some of the places to which a concealed firearm can be carried, but concealed carry is allowed in all places not mentioned in the statute or prohibited by private property owners. ${ }^{100}$ Similarly, the stand your ground law allows a person to use force wherever he "has a right to be." 101 This statute creates a problem because Kansans, in many public places, are allowed both to have concealed weapons and stand their ground in a fight. Without a duty to retreat from a violent confrontation, a greater number of people likely will use concealed firearms to protect themselves in public altercations. As mentioned above, the research on this possibility is inconclusive on both sides of the argument because of

\footnotetext{
96. Lerner, supra note 17 , at 332.

97. See infra Part III.B.3.

98. $\$ 75-7 \mathrm{c} 03$.

99. See supra Part II.D.

100. $§ 75-7 \mathrm{c} 10-11$.

101. $\$ 21-3218$
} 
the difficulty of gathering concrete evidence of defensive gun use, and because of other factors that may contribute to an increase or decrease in violent, gun-related crime. ${ }^{102}$ Therefore, it is difficult to know whether stand your ground laws generally have had this effect in concealed carry states. ${ }^{103}$ However, the probability of such an effect is not unimaginable. As explained above, ${ }^{104}$ there is persuasive statistical data that supports the argument that "shall-issue" concealed carry laws increase the number of gun-related crimes. ${ }^{105}$ Ian Ayres and John R. Donohue argue that there are several potential problems related to "shall-issue" concealed carry laws that may contribute to an increase, rather than a decrease, in crime rates. ${ }^{106}$ Ayres and Donohue argue that the adoption of shall-issue laws may "increase the speed at which a criminal decides to shoot or disable potential victims" because of the risk that any victim could be carrying a concealed weapon. ${ }^{107}$ They also contend that putting more guns into circulation is dangerous because of the rate at which weapons are stolen in this country. ${ }^{108}$ These problems may all be exacerbated by the broad and ambiguous language of Kansas's new stand your ground law.

Another problem in Kansas's stand your ground law that will be intensified by concealed carry is the lack of a reasonableness or proportionality standard. ${ }^{109}$ This omission is likely to allow too much leeway for people to react with disproportionate force-a serious problem when the force being disproportionately used comes from a concealed weapon. Because there is no reasonableness or proportionality standard to limit this use of force, it is possible that a person who uses deadly force by shooting an attacker could be protected by this statute, even if the shooter was not threatened with deadly force by his victim.

\section{B. Suggested Solutions}

There are two possible avenues available for solving the problems likely to arise as a result of the stand your ground law's ambiguous drafting. First, the legislature should amend the statute to include clear

\footnotetext{
102. See Ludwig, supra note 82 (discussing the difficulty involved in gathering conclusive data of the use of guns in self-defense).

103. Jaffe, supra note 16, at 179.

104. See supra Part II.D.

105. See generally AYRES \& DONOHUE, supra note 80.

106. Id. at 1204-06.

107. Id. at 1204 (emphasis in original).

108. Id. at 1205 .

109. See KAn. StAT. AnN. § 21-3218 (2007).
} 
definitions and a reasonableness standard. In the process, it should clarify its intent in enacting the statute. Alternatively, in interpreting the statute, Kansas courts should either clearly define the scope of the terms within the statute or interpret a reasonableness standard within the meaning of the statute.

\section{Legislative Amendment}

The Kansas Legislature should amend the stand your ground law in two ways. First, the legislature should define the terms in the statute so that they can be clearly and unambiguously applied. Second, the legislature should add a reasonableness or proportionality requirement.

By clearly defining each phrase or term of the statute, the legislature will make it easier for courts to apply the statute appropriately to the facts of individual cases. The first term that should be defined is "attack." The legislature should amend the statute to limit the scope of this term to physical attacks. This change would eliminate the possibility that a verbal attack could be met with violent, even deadly, force. The legislature should also define and limit the scope of the phrase "meet force with force," to clarify whether deadly force is permissible under the stand your ground law. Because other statutes specifically allow for the use of deadly force when reasonable, with no duty to retreat, ${ }^{110}$ it may be better to limit the stand your ground law to any force other than deadly force. It is widely accepted that a person should be able to use deadly force to protect himself from imminent death or great bodily harm. However, Kansas's defense of persons statute already permits such use of deadly force, so removing the ability to use deadly force from the general stand your ground law would not eliminate people's ability to protect themselves. The defense of persons statute is not limited by location, ${ }^{111}$ so the right to defend oneself in all places would remain intact. This change would also likely alleviate the bulk of the problems associated with concealed carry because the statute would no longer protect the use of deadly force. Indeed, this may have been the legislature's intent in excluding the right to use deadly force from the express language of the stand your ground law, but that intent is unclear, and so is the statutory language.

The second amendment to the statute should be a provision requiring reasonableness. This amendment could be done in two ways. First, the

110. E.g., id. § 21-3211.

111. Id. 
legislature could add a clause to the end of the statute limiting the applicability of the statute to instances where the use of force was reasonable under the circumstances. Because Kansas courts interpret "reasonable" in the self-defense context to mean both objective and subjective reasonableness, ${ }^{112}$ the same interpretation would likely apply to the stand your ground law. Second, a reasonableness requirement may be implicit in the statute if the terms above are clearly defined. Thus, the legislature should define the terms "attack" and "meet force with force." For example, if the statute read "meet force with reasonable or proportionate force when physically attacked," it would be clear that the legislature intended to limit the application of the statute to reasonable uses of force. If a person is not physically attacked or if he uses disproportionate - or even deadly — force, the statute would not apply. To make this change, the legislature could use, as an example, the language employed in Kansas's defense of property other than dwellings statute. ${ }^{113}$ This statute allows the use of force to protect property, and it applies a reasonableness standard. ${ }^{114}$ The statute provides that "[o]nly such degree of force or threat thereof as a reasonable man would deem necessary to prevent or terminate the interference may intentionally be used." 115 Here, the legislature clearly omitted any reference to the use of deadly force which, as stated above, could be a way to limit the stand your ground law's applicability to lesser exercises of force. Also, there is a clear requirement that the force used be in proportion to the threat, which could eliminate the possibility of unbalanced retaliation.

\section{Possible Amendments Based on Other States' Statutory Language}

Language in other states' stand your ground laws provide helpful examples of how the Kansas Legislature could amend its stand your ground law. Specifically, the Florida, Texas, and Alabama statutes provide three models that the Kansas Legislature could use in amending its stand your ground law.

a. Florida

In Florida, the language of the stand your ground statute is strikingly similar to the Kansas statute's language. The important difference is that

112. E.g., State v. Walters, 159 P.3d 174, 180 (Kan. 2007) (citation omitted).

113. § 21-3213.

114. Id.

115. Id. 
Florida's law includes a requirement for reasonableness in the use of deadly force. ${ }^{116}$ The statute provides:

A person who is not engaged in an unlawful activity and who is attacked in any other place where he or she has a right to be has no duty to retreat and has the right to stand his or her ground and meet force with force, including deadly force if he or she reasonably believes it is necessary to do so to prevent death or great bodily harm to himself or herself or another or to prevent the commission of a forcible felony.

This statute is a provision of Florida's larger defense statute. ${ }^{118}$ There is still some ambiguity in Florida's statute - the word "attack" is undefined - but it at least provides a good model for how Kansas might insert a reasonableness requirement into its stand your ground statute. Such insertion is likely the most desirable method of amendment for the Kansas statute. Kansas's stand your ground law could remain separated from the other defense statutes and provide a separate right, but still provide the necessary clarification of terms and applicability as amended. The Florida Supreme Court has not interpreted the scope of Florida's stand your ground provision, other than to determine that it does not apply retroactively. ${ }^{19}$ So, while the intended application of Florida's statute is somewhat unclear, it is a helpful example for a possible Kansas amendment.

\section{b. Texas}

In 2007, the Texas Legislature amended two of its existing selfdefense statutes to include a presumption of reasonableness in the use of force-including deadly force-to defend persons, dwellings, and occupied vehicles. ${ }^{120}$ One of these statutes allows the use of force, but not deadly force, and creates a presumption of reasonableness for the defender in various enumerated circumstances. ${ }^{121}$ The other statute provides for the use of deadly force, also creating a presumption of reasonableness in all of the same circumstances. ${ }^{122}$ These two statutes do

116. Fla. Stat. ANN. § 776.013(3) (West 2006).

117. Id. (emphasis added).

118. Id. $\$ 776.031$.

119. State v. Smiley, 966 So.2d 330, 334-35 (Fla. 2007); Thomas v. State, 918 So. 2d 327, 330 (Fla. 2005)

120. Tex. Penal Code AnN. $\S \S 9.31-9.32$ (Vernon 2007).

121. Id. $\S 9.31$.

122. Id. $\S 9.32$. 
not include a separate stand your ground provision. ${ }^{123}$ Rather, the no duty to retreat provision is included within the language of the statute allowing the use of deadly force in defense of persons. ${ }^{124}$

Although the Texas statutes differ in several ways from Kansas's stand your ground law, the Texas statutes provide three useful examples of clarifying language that could be used to improve Kansas's statute. First, Texas's statutes expressly state that the presumption of reasonableness the statutes does not apply to force used "in response to verbal provocation alone." 125 Second, the use of deadly force is specifically confined to one of the two statutes, creating a clear delineation for the application of the statutes in cases where there was a fatality. ${ }^{126}$ Finally, the statute allowing the use of deadly force provides a list of situations in which a person is presumed reasonable when using deadly force. ${ }^{127}$ The Texas statute provides that a person's

belief that the force was immediately necessary... is presumed reasonable if the actor: (1) knew or had reason to believe that the person against whom force was used... (C) was committing or attempting to commit aggravated kidnapping, murder, sexual assault, aggravated sexual assault, robbery or aggravated robbery. ${ }^{128}$

The Kansas Legislature could list certain offenses in the definition of attack, such as those included in Texas's statutes, that automatically qualify as "attacks" to make the definition even narrower than "physical attack." This approach could be problematic, though, because someone who feels the need to use deadly force to protect himself is not likely to stop and think about what offense his attacker may be committing. However, narrowing the definition of attack would provide a more systematic and predictable framework for the application of the stand your ground statute to use-of-force situations. Kansas courts could look at the circumstances of an individual case and know whether or not to apply the stand your ground statute to the facts.

123. Id. $\$ 9.31$.

124. Id. $\$ 9.32$.

125. Id. $\S 9.31(\mathrm{~b})(1)$.

126. Id. $\S \S 9.31-9.32$.

127. Id.

128. Id. $\S 9.31(\mathrm{a})(1)(\mathrm{C})$. 


\section{c. Alabama}

Alabama has a separate stand your ground provision, but it relates back to the general self-defense provision, which requires reasonableness in the use of deadly force. ${ }^{129}$ The Alabama statute provides:

A person who is justified under subsection (a) in using physical force, including deadly physical force, and who is not engaged in an unlawful activity and is in any place where he or she has the right to be has no duty to retreat and has the right to stand his or her ground. ${ }^{130}$

Subsection (a) requires that any force used must be reasonable. ${ }^{131}$ The Kansas Legislature could simply add the phrase "as provided for in K.S.A. $\S \S 21-3211 \& 21-3212$," and the stand your ground law would be governed by the same reasonableness standard as the other defense statutes. This addition would also tie in the explicit right to use deadly force, reasonable under the circumstances, that is found in the Kansas defense statutes.

\section{Narrow Court Interpretation}

If the Kansas Legislature declines to amend the stand your ground law, an alternative solution is for the court either to narrowly define the terms currently in the statute or to include a reasonableness requirement.

If the legislature does not amend the statute to define "attack," the court should interpret the "attack" provision narrowly. Because "attack" can be defined in many ways, the court should limit the definition in the stand your ground statute to include only physical attacks. This is a logical interpretation. The stand your ground law follows the other use of force statutes, which allow the use of deadly force to prevent or terminate an intrusion, or under the perceived threat of deadly force. It is easily conceivable that the legislature intended for "attack" to refer only to physical attacks. The use of the word "force" suggests an intention to limit the meaning of "attack" to physical attacks, because "force" suggests a physical, rather than verbal, attack.

The court should also interpret the "meet force with force" provision as including something less than deadly force. There is already a strong

129. ALA. CODE § 13A-3-23 (2006).

130. Id. (emphasis added).

131. Id. §13A-3-23(a). 
argument that the legislature intended to exclude deadly force in enacting the statute, because deadly force was expressly mentioned in the statutes that included a reasonableness standard. The court could make an analogy to Kansas's defense of property statute, and could distinguish the other two statutes that do allow the use of deadly force. In instances where deadly force is necessary for protection, other defense statutes would apply. As discussed above, this change would reduce or eliminate many of the problems in conjunction with the concealed carry statutes. ${ }^{132}$

An expansive interpretation of the stand your ground statute allowing for the use of deadly force without a reasonableness standard or any proportionality would make the defense of persons and defense of dwellings statutes meaningless. In other words, why would the Kansas Legislature pass a law whose intended application would totally contradict other statutes that it passes simultaneously?

Alternatively, Kansas courts could interpret the statute to include a reasonableness standard. This interpretation may be difficult because the statute's language does not include any such standard, and the rules of statutory construction emphasize that legislative intent is always the most important consideration. ${ }^{133}$ Although not clear, the legislative intent in enacting the stand your ground statute may have been to provide a catchall statute, clearly stating the rule that a victim of an attack does not have to retreat and may stand his or her ground. It is possible, maybe even likely, that the legislature never intended that deadly force would be acceptable under this statute. Deadly force was specifically mentioned in the other statutes and not in the stand your ground law. Legislative history does not provide a clear explanation of the Kansas Legislature's intent in enacting the stand your ground law. There is some indication, however, that the legislature only meant to allow the use of deadly force in the self-defense and defense of dwelling statutes. The Supplemental Note on Senate Bill No. 366, which is prepared by the Legislative Research Department, separately discusses the stand your ground law and the amendments to the defense of persons, dwellings, and occupied vehicles statutes, by restating the language of the statutes themselves. ${ }^{134}$ This Supplemental Note seems to be separating the two statutes purposely, as if to indicate that the use of deadly force, specifically

132. See supra Part III.B.1.

133. State ex. rel. Graeber v. Marion County Landfill, Inc., 76 P.3d 1000, 1008 (Kan. 2003) (“"It is a fundamental rule of statutory construction, to which all other rules are subordinate, that the intent of the legislature governs if that intent can be ascertained." (quoting In re Marriage of Killman, 955 P.2d 1228 (Kan. 1998))).

134. S.B. 366, Supplemental Note, 2006 Leg., Reg. Sess. (Kan. 2006) 
mentioned in the other defense statutes, would only be allowed in those statutes that include reasonableness standards. Unfortunately, the Supplemental Note specifically states that it is not intended to reflect legislative intent, so the meaning of this separation can only be inferred from the structure of the Supplemental Note. ${ }^{135}$

Before the original versions of the current self-defense statutes were passed, Kansas courts interpreted self-defense to include a required element of reasonableness. The original version also included a reasonableness test but did not explicitly allow deadly force. In both State v. Kelly ${ }^{136}$ and State v. Davis, ${ }^{137}$ the Kansas Supreme Court held that the use of force in self-defense had to be reasonable, even in the absence of a statute. The problem now is that there is a controlling statute that includes no mention of reasonableness in the use of force, so the court may be hesitant to interpret the statute to mean something the statute does not expressly say. The legislature knew how to include a reasonableness requirement and left it out of the stand your ground law. The defense statutes were amended at the same time the stand your ground law was drafted, ${ }^{138}$ and it seems unlikely that the legislature would add a reasonableness standard to two existing statutes and leave it out of a newly drafted one unless it was intentional. Whether the legislature intended to omit a reasonableness requirement is unclear, which unfortunately means that it would be difficult for a Kansas court to interpret a reasonableness requirement into the statute based on the current mandates of statutory construction.

Because interpreting a reasonableness standard into the statute may be difficult based on the statute's language and the rules of statutory construction, the better option may be for courts to expressly define what the terms in the statute should mean and how they should be applied. This approach poses less of a problem in terms of statutory construction because the terms are not defined in any way by the statute, and they have to mean something specific. In other words, because the terms are already in the statute, they can be given various meanings. But without any express reasonableness requirement, Kansas courts will not likely add one into the language.

135. Id.

136. 291 P. 945 (Kan. 1930)

137. 218 P.2d 215 (Kan. 1950)

138. Compare KAn. StAT. ANN. § 21-3218 (2006), with §§ 21-3211-12. 


\section{Practical Implications of Suggested Changes}

As between the two proposed remedies, a legislative amendment would be the most effective means of clarifying the statute. An amendment would summarily clear up any confusion as to the legislative intent in enacting the statute, provided the legislature explained its intent, and it would provide important boundaries for a statute that now seems unnecessarily inclusive. If the legislature specifically excluded deadly force from the stand your ground statute, it would help alleviate the problem associated with the stand your ground law in conjunction with concealed carry. If Kansans carrying guns were not able to use them unreasonably while standing their ground in a fight, the likelihood of the problems mentioned above would be decreased or eliminated. Also, a statutory amendment would give the Kansas Legislature the opportunity to distinguish the purpose of the stand your ground law from the purposes of the other amendments to defense statutes.

A narrow interpretation by the Kansas courts could also provide a great deal more direction in the application of the stand your ground law. Once the applicability of the statute is clearly determined, the possible problems associated with disproportionate retaliations should be diminished. With each new decision from the Kansas courts applying the stand your ground law to different factual circumstances, the definitions of the statute's terms would become clearer and the uncertainty of the statute's scope would eventually be eliminated.

\section{CONCLUSION}

In conjunction with concealed carry, the stand your ground law may protect a person who uses unnecessarily harsh or even deadly force against an "attacker." The precise outcome, however, is unfortunately difficult to predict because of the ambiguous nature of the terms of the statute. There are two practical ways to avoid or control this possibility. The first is for the Kansas Legislature to amend the statute, and the second is for the Kansas courts to interpret the statute narrowly.

To best control the results generated by Kansas's stand your ground law, the legislature should amend the law to limit its applicability, especially in the use of disproportionate deadly force. The terms "attack" and "meet force with force" in the stand your ground law should be expressly and narrowly defined, and a requirement of reasonableness or proportionality should be added to minimize the possibility for disproportionate retaliation. The legislature also could limit the applicability of the statute by expressly disallowing the use of deadly 
force under the stand your ground law, leaving those situations squarely in the purview of Kansas's other defense laws.

If the legislature chooses not to amend the statute, it will be up to the courts to determine how to shape the meaning of the statute. To do this, the courts should narrowly interpret the terms mentioned above, excluding verbal attacks from the definition of "attack" and requiring proportional force. Kansas courts may also attempt to interpret a reasonableness standard into the statute, although this would likely prove problematic based upon Kansas's common law rules of statutory construction.

Regardless of the method chosen by the legislature or the courts, the stand your ground law cannot effectively be applied or interpreted as written without creating unwanted and dangerous results. Some government action is necessary to protect Kansans from each other and from themselves. 